\title{
Aplikace práva duševního vlastnictví v rámci divadelního provozu aneb Autorský zákon je teprve začátek
}

\section{Application of the Intellectual Property Right in Theatre Management or The Copyright Law is Only a Beginning}

Martina Hájková

\begin{abstract}
Abstrakt
Př́spěvek se věnuje aplikaci práva duševního vlastnictví na divadelní provoz. Snaží se upozornit na nutnost využití dalších oblastí práva duševního vlastnictví, nejen oblastí obsažených $\checkmark$ autorském zákoně, a to s ohledem na různost činností a situací, které nastávají v rámci divadelního provozu.

\section{Klíčová slova}

divadlo, právo duševního vlastnictví, divadelní provoz, autorské právo, patentové právo, ochranné známky, nekalá soutěž, ochrana osobnosti, obchodní tajemství
\end{abstract}

\begin{abstract}
The present study discusses the employment of intellectual property right in theatre management. The author aims at stressing the necessity of applying the concept of intellectual property right - besides the cases concerning the copyright - also to other situations and issues of theatre management.
\end{abstract}

\section{Keywords}

theatre, intellectual property right, theatre management, copyright, patent law, trademark, unfair competition, personality protection, trade secret 


\section{Právo duševního vlastnictví}

Motivací k sepsání této studie byl nedostatek materiálů věnujících se speciálně aplikaci práva duševního vlastnictví na divadelní oblast. Z tohoto důvodu si předkládaná studie klade za cíl pokusit se analyzovat tuto oblast a vybraná práva relevantní pro divadelní provoz podrobněji rozebrat především s ohledem na příklady z praxe.

Co je duševní vlastnictví? Česká právní úprava nám jednoznačnou odpověd’ nenabízí. Z tohoto důvodu jsem vycházela z mezinárodněprávní úpravy (viz dále v textu) a doplnila ji o poznatky z teoretických oblastí. Předložená studie vychází z mé diplomové práce „Právo duševního vlastnictví v kontextu divadelního provozu“, která byla obhájena 7. června 2016 na Katedře produkce Divadelní fakulty Akademie múzických umění v Praze. ${ }^{1} \mathrm{~V}$ průběhu výzkumu jsem zjistila, že povědomí o právu duševního vlastnictví je v divadle vyšší, než jsem se původně domnívala. Problémem ovšem zůstává, že v rámci divadelního provozu chybí čas - a velmi často i vůle - zabývat se něčím nad rámec nezbytně nutných právních úkonů. Částečně to může být dáno i tím, že divadla spoléhají na to, že nejsou pod takovým drobnohledem nad dodržováním jednotlivých práv duševního vlastnictví.

Právo duševního vlastnictví upravuje vztahy vznikající při lidské tvưrčí činnosti. Jednotlivá práva duševního vlastnictví jsou svou povahou práva absolutní, tedy působí erga omnes. Literatura dělí právo duševního vlastnictví do dvou základních oblastí: autorské právo, práva př́buzná autorskému právu a práva související s autorským právem; dále rozlišuje průmyslová práva a práva obdobná průmyslovým právům.

Jak jsem již zmínila výše, český právní řád definici duševního vlastnictví neobsahuje. Vycházím tedy z definice obsažené v Úmluvě o zřízení Světové organizace duševního vlastnictví (dále jen „WIPO“2) ze dne 14. července 1967 a ze Směrnice Evropského parlamentu a Rady 2004/48/ES ze dne 29. dubna 2004 o dodržování práv duševního vlastnictví, v kombinaci s prohlášením Komise 2005/295/ES týkajícího se článku 2 této směrnice.

Čl. 2 (viii) Úmluvy o zřízení WIPO stanovuje práva duševního vlastnictví v kontextu úmluvy: k literárním, uměleckým a vědeckým dílům; práva výkonného umělce k uměleckému výkonu, práva výrobce zvukového záznamu k jeho záznamu, práva výrobce zvukově obrazového záznamu k jeho prvotnímu záznamu a práva rozhlasového a televizního vysílatele k jeho vysílání; k vynálezům ze všech oblastí lidské činnosti; k vědeckým objevům; k průmyslovým vzorům a modelům; k továrním, obchodním známkám a známkám služeb, jakož i k obchodním jménům a obchodním názvům; na ochranu proti nekalé soutěži; a všechna ostatní práva vztahující se k duševní činnosti v oblasti průmyslové, vědecké, literární a umělecké.

Směrnice Evropského parlamentu a Rady 2004/48/ES v souladu s výkladovým prohlášením Komise 2005/295/ES určuje oblasti působnosti směrnice velmi podobně jako

1 Vedoucí práce prof. JUDr. Jiří Srstka, oponent prof. Ing. Ladislav Jakl, CSc.

$2 \mathrm{Z}$ anglického názvu World Intellectual Property Organization. 
úmluva: autorské právo; práva př́ibuzná právu autorskému; zvláštní právo pořizovatele databází; práva tvůrce topografií polovodičových výrobků; práva k ochranným známkám; práva $\mathrm{k}$ (průmyslovým) vzorům; patentová práva včetně práv odvozených z dodatkových ochranných osvědčení; zeměpisná označení; práva k užitným vzorům; odrůdová práva; obchodní jména, jsou-li chráněna jako výhradní vlastnická práva v dotčeném vnitrostátním právu.

Hlavním smyslem práva duševního vlastnictví je poskytnutí právního rámce autorům, resp. původcům či majitelům zákonem specifikovaných nehmotných statků považovaných za duševní vlastnictví, aby mohli předměty duševního vlastnictví plně chránit, využívat a disponovat s nimi. Právní rámec je kombinací soukromoprávních nástrojů $\mathrm{s}$ veřejnoprávními (proces přihlašování a rozhodování o ochraně).

Duševní vlastnictví je ve většině případů vnímatelné přes jeho hmotné ztvárnění (na papíře, fotografii, obrazovém či zvukovém záznamu), jeho využívání je však na hmotném substrátu zcela nezávislé. Nehmotný statek je totiž možné současně vnímat či používat kdykoli a kdekoli, a to bez změny jeho podstaty a funkce. Jednoduše řečeno, na nehmotné statky jako takové se vztahují práva osobní povahy, ale na jejich hmotný substrát se aplikují předpisy vlastnického práva.

Já jsem při definování duševního vlastnictví vycházela z extenzívního výkladu Petera Vojčíka a oproti definicím využívaných WIPO a výkladů uvedených ve směrnici jsem do definice navíc zařadila jednotlivé stránky osobnosti člověka (chráněny v rámci ochrany osobnosti); hmotně zachycené projevy osobnosti člověka, písemnosti osobní povahy, podobizny, obrazové snímky, obrazové a zvukové záznamy týkající se fyzické osoby nebo jejích projevů (taktéž chráněny v rámci ochrany osobnosti) a ostatní nehmotné statky jako zbytkovou kategorii pro ty, které nejsou zařaditelné do předchozích kategorií. ${ }^{3}$

Pro úplnost ještě uvádím, že s nehmotnými statky souvisí ještě $§ 2631$ zákona č. 89/2012 Sb., občanský zákoník, ve znění pozdějších předpisů (dále jen „občanský zákoník“), který definuje dílo s nehmotným výsledkem jako „výsledek díla, činnost, která není hmotně zachycena“. Zákonem je oproti hmotnému dílu požadována vyšší péče, tedy nikoli pouze potřebná péče, ale péče odborná. K jeho vytvoření může být navíc zapotřebí i nějaký výkon či tvůrčí umělecký nebo vědecký čin.

\section{Divadelní provoz a právo duševního vlastnictví}

Divadelní provoz je široký pojem, jehož obsah se liší podle typu divadla. Česká divadelní sít je velmi pestrá, zahrnuje jak instituce vícesouborových divadel, tak nezávislé soubory bez stálé scény. Vedení nezávislých divadelních souborů mnohdy některé

3 Do této kategorie by se daly řadit výsledky různých vědeckých a výzkumných prací (včetně školních a kvalifikačních), principy, objevy a informace jako obsah autorských děl, které autorské právo nechrání, či je dokonce vylučuje z předmětu ochrany, jako jsou právní předpisy, úřední rozhodnutí apod. Některé mají výlučného vlastníka a ty, které nemají, jsou označeny jako veřejné duševní vlastnictví, zpravidla pod správou státní či veřejné instituce a jsou chráněny všeobecnými právními předpisy. 
legislativní potíže příliš neřeší a z pohledu práva fungují poněkud „volněji“. ${ }^{4}$ Pro účely tohoto příspěvku zahrnuji pod divadelní provoz všechny činnosti a vztahy, které v rámci něho vznikají a je nutné je řešit, tedy uměleckou činnost, technicko-provozní správu, výrobu, jevištní provoz, marketing, management a další činnosti.

$\mathrm{Z}$ práva duševního vlastnictví jsou pro divadlo $\mathrm{k}$ dalšímu rozpracování relevantní oblasti autorského práva a práva souvisejícího s právem autorským, patentové právo, užitné vzory, průmyslové vzory, know how a obchodní tajemství, ochranné známky, loga a doménová jména, ochrana osobnosti člověka a názvu a dobré pověsti právnické osoby a problematika nekalé soutěže. Nebot' existuje velké množství publikací, stejně tak i diplomových prací věnujících se autorskému právu a právưm souvisejícím s právem autorským, rozhodla jsem se tuto část práva duševního vlastnictví v tomto příspěvku zcela vynechat a zaměřit se na více opomíjené oblasti.

\section{Patentové právo}

Za splnění podmínek dle zákona č. 527/1990 Sb., o vynálezech a zlepšovacích návrzích (dále pouze „VZN“)5 je možno žádat Úřad průmyslového vlastnictví (dále jen „ÚPV“) o udělení patentu pro výsledky technické tvưrčí činnosti. Při kumulativním splnění podmínek jsou patentovatelné vynálezy, které jsou nové, výsledkem vynálezecké činnosti a jsou využitelné průmyslově. Rozsah ochrany z patentu je vymezen zněním patentového nároku a může být udržován maximálně dvacet let od podání přihlášky. ${ }^{6}$

Potenciál na patentování, případně na registrování užitného vzoru dle úrovně řešení, mají v divadle především výsledky činnosti scénografů, světelných designerů a technických pracovníků, a to ve třech oblastech: vlastní technologie jeviště, světlo a zvuk. Z mého úhlu pohledu se mi jeví pro divadla účelnější a snadněji dosažitelné využití ochrany poskytované užitným vzorům (viz další kapitola).

Patentovat lze i podnikatelský záměr, a to za předpokladu, že splní zákonem stanovené podmínky, v první řadě novost. V případě, že podnikatelský záměr nesplní zákonem stanovené podmínky, lze uvažovat o ochraně jako užitného vzoru, případně ho chránit jako obchodní tajemství.

U patentového práva v divadle je nutné zohlednit nejen možnost patentovat vynález vytvořený v divadle, ale především použití patentů vzniklých mimo divadlo. Udržování patentů je poměrně drahé a vidina hospodářského prospěchu z patentu pro divadlo je mizivá. U použití patentů „zvenčí“ divadelního světa je naopak tendence jejich ochranu obcházet a vytvořit si svépomocí „něco podobného“.

4 Toto je dáno zejména tím, že nezávislé divadelní soubory většinou nemají zaměstnance, nevlastní, případně nemají ve správě, nemovitosti apod., tedy nejsou tolik pod kontrolou.

5 Dále tuto problematiku upravuje zákon č. 417/2004 Sb., o patentových zástupcích a o změně zákona o opatřeních na ochranu průmyslového vlastnictví a vyhláška č. 550/1990 Sb., o řízení ve věcech vynálezů a průmyslových vzorů.

6 Účinky patentu nastávají až ode dne oznámení o udělení patentu ve věstníku ÚPV. U mezinárodní přihlášky o udělení patentu účinky v České republice nastanou až po zveřejnění jejího překladu. 
Další překážkou kromě finanční náročnosti udržení patentu je pro divadla i nutnost udělat pro jeho vznik další úkony, zejména podat přihlášku vynálezu se žádostí o udělení patentu. ${ }^{7}$ Dalšími bariérami je splnění formálních náležitostí (především kritérium průmyslové využitelnosti) a časová náročnost celého procesu. ÚPV každou přihlášku předběžně přezkoumá, zda neobsahuje předměty zjevně nepatentovatelné, nejednotné, či zda nemá přihláška vady, kvůli kterým nemůže být zveřejněna. Po uplynutí 18 měsíců od vzniku práva přednosti ÚPV přihlášku zveřejní a oznámení publikuje ve věstníku ÚPV. Úplný průzkum patentovatelnosti se však provádí až na základě žádosti přihlašovatele, kdy tato žádost musí být podána do 36 měsíců od podání přihlášky. ÚPV udělí patent až na základě tohoto průzkumu, pokud vynález splňuje všechny podmínky.

Celoevropsky se objevuje snaha omezit trvání patentové ochrany, a z tohoto důvodu je udržování patentu každý rok dražší. Za první rok je poplatek 1000 Kč, za prodloužení o rok ve dvacátém roce již 24000 Kč. ${ }^{8}$

ÚPV má patentovou tř́idu speciálně věnovanou divadlu, přesněji řečeno se jedná o třídu A63J dle Mezinárodního patentového třídění „Zařízení pro divadla, cirkusy a podobně; kouzelnické předměty a podobně“. Aktuálně nejsou pod třídou A63J registrovány platné patenty, pouze patenty ze šedesátých let (18 záznamů $\left.{ }^{9}\right)$, z nichž nejznámější byly patentovány kolektivem vytvořeným kolem scénografa Josefa Svobody. ${ }^{10}$ Jako příklad můžeme uvést jeho nízkovoltové rampy, oponu, či světelný most. Konkrétně nízkovoltové rampy vznikly ve spolupráci se specialisty z firmy ADB, proto se jim říká bud' ADB rampy, nebo rampy Svoboda. Pod jménem rampy Svoboda jsou známé i v zahraničí. ${ }^{11}$

Svítidlo DPR 2250 dříve známé jako SVOBODA rampa bylo vyvinuto známým českým scénografem Josefem Svobodou, který po dlouhou dobu usiloval o vytvoření dramatičnosti scény pouhým světlem. Výsledkem bylo svítidlo DPR 2250 (SVOBODA), rampa o výkonu $2250 \mathrm{~W}$ složená z devíti $24 \mathrm{~V}$ reflektorů, vytvářející velice silný pás úzkého světla, tzv. světelný závěs. ${ }^{12}$

Domnívám se, že i v dnešní době může docházet k patentování předmětů či věcí z divadla, ale děje se tak pod jinou třídou, nikoli specificky pod třídou A63J.$^{13}$

7 Dle mých výpočtů v souladu se sazebníkem dle zákona č. 634/2004 Sb., o správních poplatcích, jsou náklady na patentování minimálně 5200 Kč.

$8 \quad$ Poplatky ke dni 1. 4. 2016.

9 Dle databáze dostupné na www.upv.cz.

10 Pro úplnost uvádím, že při konzultaci diplomové práce s Bedřichem Gregorinim a profesorem Jiřím Srstkou jsme narazili i na další př́klady z praxe, u kterých by stálo za to uvažovat o jejich možné patentovatelnosti, např. černé divadlo, mechanická clona na světla, projekce na divadle, bobinet (tyl na rám), vodní sprchy jako lapač prachu (Karel Krček), polopropustná zrcadlovka a další. Pokud jde o využití patentů z jiných oborů v divadle, tak bych uvedla alespoň vzduchové polštáře využívané v leteckém průmyslu při přistání na břiše, krupičkové zlato, které nevadí vdechnout (Jan Antonín Pitínský použil v inscenaci Tristan a Isolda), titulkovací zařízení apod.

11 Oto teatr [online]. [citováno dne 1. 4. 2016]. Dostupné online na http://oto-teatr.tv/adb/rampy-svoboda/.

12 ArtLighting [online]. [citováno dne 1. 4. 2016]. Dostupné online na http://www.artlighting.cz/dpr-2250/.

13 Při fulltextovém vyhledávání slova „divadlo“ jsem narazila pouze na přihlášku „rotační pohonné jednotky pro zvedací a spouštěcí zařízení", ale patent v této věci nebyl zatím udělen. 
Na závěr bych chtěla upozornit na speciální úpravu oproti úpravě licenčních smluv v občanském zákoníku. Pro účinnost je u licenčních smluv na patenty vyžadován zápis do patentového rejstř́ku. Existuje specifická možnost prohlásit u ÚPV, že přihlašovatel poskytne právo k využití vynálezu komukoli, kdo písemně přijme a uhradí cenu licence.

\section{Užitné a průmyslové vzory}

Užitné vzory jsou v českém právním řádu upraveny v zákoně č. 478/1992 Sb., o užitných vzorech. Užitnými vzory se chrání nová technická řešení, která přesahují rámec odborné dovednosti a jsou průmyslově využitelná. Užitný vzor lze udržovat maximálně deset let.

Průmyslové vzory upravuje zákon č. 207/2000 Sb., o ochraně průmyslových vzorů a o změně zákona č. 527/1990 Sb., o vynálezech, průmyslových vzorech a zlepšovacích návrzích, ve znění pozděǰ̌ích předpisů. Průmyslovým vzorem se dle $\$ 2$ výše zmíněného zákona rozumí „vzhled výrobku nebo jeho části, spočívající zejména ve znacích linií, obrysů, barev, tvaru, struktury nebo materiálů výrobku samotného, nebo jeho zdobení.“ Průmyslový vzor je způsobilý ochrany, je-li nový a má-li individuální povahu. Ochranu je možné prodlužovat až na celkovou dobu 25 let.

Právě ochrana prostřednictvím užitných vzorů by mohla být ideálním řešením pro oblast divadla. Tato ochrana je oproti patentům jednodušší, rychlejší a méně nákladná. Užitným vzorem jsou nová, průmyslově využitelná technická řešení, která přesahují rámec pouhé odborné dovednosti, tedy u nich není užita vynálezecká činnost. Podmínky pro udělení ochrany se oproti patentům liší požadavkem na úroveň řešení.

Základní rozdíl spočívá v ř́izení o přihláškách užitných vzorů. Řízení je založeno na tzv. registračním principu, ÚPV zkoumá pouze splnění základních podmínek pro ochranu a užitný vzor zapíše do rejstř́íku, aniž by zkoumal, zda předmět přihlášky je z hlediska novosti a tvůrčí úrovně způsobilý k ochraně. Tím, že užitný vzor se zapisuje do rejstř́k bez průzkumu novosti a úrovně řešení, je jeho monopol oproti patentu křehký a postavení jeho majitele méně jisté. Výhodou však zůstávají mnohem nižší poplatky a rychlejší zápis (zpravidla tři až čtyři měsíce od podání přihlášky) ${ }^{14}$ Doba ochrany užitného vzoru trvá pouze čtyři roky, ale na žádost majitele může být prodloužena dvakrát o tři roky. Maximální doba ochrany je tedy 10 let.

Ochrana typu průmyslových vzorů by se dala nejvhodněji použít pro specifický vzhled některých „výrobků“ v divadle, především v oblasti scénografie.

\section{Know-how a obchodní tajemství}

Obchodní tajemství je definováno v § 504 občanského zákoníku. „Obchodní tajemství tvoří konkurenčně významné, určitelné, ocenitelné a v př́slušných obchodních kruzích běžně nedostupné skutečnosti, které souvisejí se závodem a jejichž vlastník

14 Za určitých podmínek je možné z původní přihlášky vynálezu odbočit na přihlášku užitného vzoru při zachování původní priority. 
zajištuje ve svém zájmu odpovídajícím zpo̊sobem jejich utajení.“ Obchodní tajemství zaniká zpřístupněním jiným osobám (zákonným či nezákonným), ukončením utajování jeho vlastníkem.

Termín know-how se vyskytuje u ochrany hospodářské soutěže. Lze ho vymezit tak, že jde o soubor nepatentovaných praktických poznatků vyplývajících ze zkušeností a testování jeho vlastníka, případně jako souhrn organizačních, řídících, ekonomických, podnikatelských a technických znalostí a zkušeností. Tyto poznatky jsou utajené, podstatné a identifikovatelné. Identifikovatelné znamená, že je někde popsáno nebo zaznamenáno dostatečně podrobně, aby se dle toho dala ověřit tajnost a podstatnost.

Je třeba upozornit, že součástí know-how může být i nepatentovaný (případně nepatentovatelný) vynález. Majitel know-how však nemůže zakázat dispozici s tímto řešením. Pokud by někdo toto řešení vyzradil, náhrada, kterou po něm bude moct majitel know-how požadovat, nikdy nebude taková, jakou by mohl požadovat v případě zneužití patentu. Stejně jako nepatentovaný vynález může být součástí know-how i neregistrovaný užitný či průmyslový vzor. Zlepšovací návrhy jsou v podstatě vždy součástí know-how.

Mezi oběma termíny není přiliš velký rozdíl a dalo by se říci, že know-how vlastně spadá pod obchodní tajemství, v praxi jsou však oba pojmy zaměňovány.

Divadla si obecně málo střeží své konkurenční výhody. Př́ikladem by mohly být databáze diváků, které naplňují všechny znaky definice $\$ 504$ občanského zákoníku. Zejména u vícesouborových divadel se nabízí využití této ochrany u systému sestavování repertoáru. Dalšími možnostmi uplatnění ochrany jsou smluvní vzory nebo způsob získávání nových abonentů, diváků či sponzorů.

Otázkou zůstává, zda by způsob získávání nových abonentů, diváků či sponzorů naplnil podmínku, že jde o skutečnosti v příslušných obchodních kruzích běžně nedostupné. Teorie marketingu a audience developmentu pracuje s určitými postupy a metodami, které jsou brány za standard. Záleželo by na posouzení konkrétního případu.

Dalším znakem je ocenitelnost. Ocenitelné je něco, co má potenciální materiální či nemateriální hodnotu. Takovou hodnotu bude mít tehdy, pokud se vyzrazení obchodního tajemství dotkne současného, případně budoucího hospodářského výsledku podniku.

Zda něco je, či není obchodním tajemstvím, se řeší většinou až v případě sporu. Pokud divadla něco ze své činnosti považují za předmět obchodního tajemství, měla by se k tomu náležitě chovat a chránit si to. Vhodné je mít upraveno ve smlouvách v ustanoveních o mlčenlivosti. V ideálním případě mít i jednotlivé části označeny za předmět obchodního tajemství, jelikož dle judikatury nelze obsah celé smlouvy považovat za obchodní tajemství.

\section{Ochranné známky}

Ochranné známky jsou upraveny v zákoně č. 441/2003 Sb., o ochranných známkách a o změně zákona č. 6/2002 Sb., o soudech, soudcích, přísedících a státní správě soudů a o změně dalších zákonů, ve znění pozdějších předpisů (dále jen „zákon o ochranných 
známkách“). ${ }^{15}$ Ochrannou známkou může být dle $§ 1$ výše zmíněného zákona za podmínek tímto zákonem stanovených ,jakékoliv označení schopné grafického znázornění, zejména slova, včetně osobních jmen, barvy, kresby, písmena, číslice, tvar výrobku nebo jeho obal, pokud je toto označení způsobilé odlišit výrobky nebo služby jedné osoby od výrobků nebo služeb jiné osoby.“

Ochranné známky mají několik funkcí: identifikační, rozlišovací, ochrannou, garanční, propagační, stimulační a soutěžní.

Na území České republiky se vyskytují čtyři typy ochranných známek s ohledem na jejich územní působnost: národní ochranné známky, mezinárodní ochranné známky, ochranné známky Evropské unie a všeobecně známe známky ve smyslu článku 6bis Pařižské úmluvy na ochranu průmyslového vlastnictví. V souvislosti s užíváním ochranné známky je oprávněn užívat značku ${ }^{\circledR}$. Platnost zápisu je deset let a lze jej obnovovat vždy o dalších deset let, a to bez omezení.

Velmi často se ve spojitosti s ochrannými známkami zmiňuje logo jako jedna z možností ztvárnění ochranné známky. „Logo je grafické ztvárnění názvu organizace, společnosti, firmy nebo instituce obohacené o piktogram. Tento pojem odpovídá českému výrazu grafická značka." ${ }^{16}$

S ochrannými známkami úzce souvisí domény, zjednodušeně adresy webových stránek složené z unikátního názvu a názvu tzv. TLD ${ }^{17}$. V České republice neexistuje zvláštní zákon zabývající se problematikou registrace doménových jmen, lze využít opět zákon o ochranných známkách. V př́ípadě, že je registrované doménové jméno shodné, případně zaměnitelné s dř́ve zapsanou ochrannou známkou, je to výhoda pro př́padný spor o doménové jméno pro vlastníka ochranné známky. Otázkou vždy zůstává skutková podstata celého sporu, především zda je ochranná známka registrována pro stejnou skupinu výrobků a služeb. Může se jednat o projev nekalé soutěže. Dalšími možnostmi je využití institutu ochrany názvu právnické osoby, ochrany obchodní firmy podnikatele či ochrany před nekalou soutěží.

„Značka“ je další z konkurenčních výhod divadel při komunikování jejich produktů. Divadla jsou zařazena dle TMclass $^{18}$ u služeb pod tř́ídou 41. V České republice není ochrana „značek“ divadly stále obecnou praxí. Pod touto tř́ídou lze dohledat $45^{19}$ registrovaných platných ochranných známek s upřesněním „divadlo“, 13 z nich má ovšem registrováno Národní divadlo v Praze.

Pokud bychom si chtěli pro divadlo zaregistrovat například ochrannou známku „Romeo a Julie“, pravděpodobně nám bude registrace zamítnuta pro absenci rozlišitelnosti ochranné známky. Pokud bychom však registrovali stejný název pro parfém, již by zde rozlišitelnost byla a známka by nám pravděpodobně byla zapsána.

15 Prováděcí vyhláška k tomuto zákonu je č. 97/2004 Sb., k provedení zákona o ochranných známkách.

16 Dostupné online na http://unie-grafickeho-designu.cz/vlastnosti-dobreho-loga-obsahlyclanek/\#.VVIDpiHtmko.

17 Top-level domain, což je v České republice například koncovka „.cz“.

18 Komplexní nástroj tř̌́dění Úřadu Evropské unie pro duševní vlastnictví (dále jen „EUIPO“) a národních úřadů EU.

19 Údaj ke dni 1. 4. 2016. 
Pokud jde o obchodní firmu, obchodní firma se nechápe výlučně jako právo osobní, ale spíše jako majetkové právo, proto je možné s ní lépe majetkově disponovat.

Jak jsem již zmínila výše, nejvíce ochranných známek má registrováno Národní divadlo v Praze. Má jak slovní, grafické, tak kombinované ochranné známky. Dále má rozlišené ochranné známky jak pro celé divadlo, tak pro některé scény či produkty. Existují např́k lad ochranné známky pro Stavovské divadlo, Laternu Magiku, Ples v opeře a další. Je tak vidět, že ochranná známka může být použitelná i pro nějaký „produkt“ či část divadla, nejen pro název divadla jako takového.

\section{Ochrana osobnosti člověka, ochrana názvu a pověsti právnické osoby}

Osobnostní práva sice nelze fakticky „vlastnit“, ${ }^{20}$ ale zařazuji je jako součást práv k nehmotným statkům. Dají se rozdělit na všeobecná a zvláštní. Všeobecná osobnostní práva se týkají lidské osobnosti jako takové, zvláštní osobnostní práva souvisí s duševní činností člověka, jejich ochrana tedy není poskytnuta všem. Zaměřuji se pouze na ta obecná osobnostní práva fyzických osob zaručená Listinou základních práv a svobod (dále jen „Listina“)21 a občanským zákoníkem.

Článek 7 Listiny v prvním odstavci zaručuje nedotknutelnost osoby a jejího soukromí. Omezena může být pouze v případech stanovených zákonem. Článek 10 dále upravuje právo každého na zachování jeho lidské důstojnosti, osobní cti, dobré pověsti a k ochraně jeho jména, práva na ochranu před neoprávněným zasahováním do soukromého a rodinného života a práva na ochranu před neoprávněným shromaždováním, zveřejňováním nebo jiným zneužíváním údajů o jeho osobě. Článek 13 upravuje ochranu listovního tajemství a jiných písemností a záznamů uchovávaných v soukromí nebo zasílaných. ${ }^{22}$

Občanský zákoník doplňuje Listinu $\$ 3$ odst. 2, písm. a), který stanovuje jednu ze zásad soukromého práva, že „každý má právo na ochranu svého života a zdraví, jakož i svobody, cti, důstojnosti a soukromí." Tuto zásadu dále rozvíjí $§ 84$ až $§ 90$ občanského zákoníku týkající se podoby a soukromí člověka. Zachytit podobu člověka jakýmkoli způsobem, pokud je člověk identifikovatelný, je možné pouze s jeho svolením, taktéž jeho podobu rozšiřovat. Pokud člověk svolí k použití písemnosti osobní povahy, podobizny nebo zvukového či obrazového záznamu nebo jeho projevů osobní povahy, může svolení odvolat a to i v případě, že je udělil na dobu určitou. ${ }^{23}$ Zákon stanovuje výjimky, kdy svolení není třeba (vědecká, umělecká, úřední, tisková, rozhlasová a další zákonné licence). §90 občanského zákoníku stanovuje pro zákonné licence kritérium přiměřenosti: „Zákonný důvod k zásahu do soukromí jiného nebo k použití jeho podobizny,

20 Dělení viz (VOJČí́K 2012: 25).

21 Ústavní zákon č. 2/1993 Sb., ve znění ústavního zákona č. 162/1998 Sb.

22 I v prrípadě předávání zpráv telefonem, telegrafem či podobným zařízením.

23 Pokud je svolení na dobu určitou odvoláno bez podstatné změny okolností nebo jiného rozumného důvodu, nahradí odvolávající škodu z toho vzniklou osobě, které svolení udělil. 
písemnosti osobní povahy nebo zvukového či obrazového záznamu nesmí být využit nepřiměřeným způsobem v rozporu s oprávněnými zájmy člověka.“

Za určitých podmínek a se souhlasem oprávněné osoby se některé projevy osobní povahy mohou stát předmětem smluvního vztahu. Typickým př́íladem je použití osobní fotografie fyzické osoby s jejím souhlasem pro autorské dílo. Tím se dostane jako umělecká fotografie pod ochranu AZ. Osobní písemnosti se taktéž mohou dostat pod ochranu autorského zákona, pokud jsou použity jako autorské dílo.

U divadla jsou důležité zejména otázky dodržování ochrany osobnosti člověka, ochrany názvu a dobré pověsti divadla. Rozšíření okruhu oprávněných osob domáhat se postmortálně ochrany osobnosti zasahuje i do divadelního provozu. Tím, že je nově aktivně legitimována i právnická osoba, pokud neoprávněný zásah souvisel s činností zesnulého v této právnické osobě, budou se tak této ochrany domáhat i divadla.

Nejčastěji dochází k zásahu do ochrany osobnosti při inscenování hry o reálné osobě, a to také již po její smrti, př́ípadně se používá zvukový nebo zvukově-obrazový záznam konkrétní fyzické osoby. U ochrany osobnosti záleží, jestli je osoba veřejně činná nebo se jedná o soukromou osobu. U veřejně činných osob (od osob ze showbyznysu po politiky) má ochrana osobnosti nižší standard. Pokud jsou osoby veřejně činné, musí být připraveny na určitý zásah do soukromí.

V A Studiu Rubín bylo např́íklad uvedeno nejprve scénické čtení, poté inscenace Blond’atá bestie, které přímo vycházelo z odposlechů Kristýny Kočí z politické strany Věci veřejné. Dalším př́ikladem využití reálné kauzy veřejně činných osob by mohla být inscenace Ivánku, kamaráde, můžeš mluvit? Petra Čtvrtníčka, která vznikla na základě materiálu z korupčního skandálu Českomoravského fotbalového svazu. V těchto př́ípadech jsou reálné osoby nezpochybnitelně identifikovatelné, ale vzhledem $\mathrm{k}$ jejich veřejné činnosti to není v rozporu s právem. Ochrana jejich osobnosti se v případě veřejného zájmu blíží dokonce nule.

Na druhou stranu inscenace souboru Depresivní děti toužící po penězích Milostný dopis ženě, kterou nemilujeme je založen na reálné korespondenci a setkání protagonistů představení s náhodně vybranou soukromou osobou. Pět mužů složilo v rámci dokumentárního představení z e-mailů, SMS, inzerátu a setkání „obraz“ jedné ženy. Pokud by ona dotyčná žena mohla být na základě uvedených informací identifikována, již by se dostali do střetu s ochranou osobnosti. Vzhledem k tomu, že ji nelze na základě dostupných informací identifikovat, nedostanou se tvůrci do střetu se zákonem.

Pokud se jedná o použití zobrazení fyzických osob, můžeme hovořit o dvou rovinách: prosté použití zobrazení umělce v programu, což je většinou ošetřeno v pracovní smlouvě, a použití zobrazení fyzické osoby v divadle.

V případě použití osobní korespondence se velmi často zapomíná, že je pro její použití nutný souhlas nejen pisatele, ale i adresáta. 


\section{Nekalá soutěž}

Nekalá soutěž souvisí především s problematikou průmyslových práv, konkrétně s know-how, obchodním tajemstvím, názvem a pověstí právnické osoby a i WIPO ji zařazuje do oblasti duševního vlastnictví.

Nekalá soutěž je upravena v občanském zákoníku (§ 2976 a následující občanského zákoníku) a je definována tak, že „kdo se dostane v hospodářském styku do rozporu s dobrými mravy soutěže jednáním způsobilým přivodit újmu jiným soutěžitelům nebo zákazníkům, dopustí se nekalé soutěže." Nekalá soutěž je zákonem explicitně zakázána.

Nekalou soutěží je podle $\$ 2976$ odst. 2 občanského zákoníku zejména: klamavá reklama, klamavé označení zboží nebo služby, vyvolání nebezpečí záměny, parazitování na pověsti závodu, výrobku či služeb jiného soutěžitele, podplácení, zlehčování, srovnávací reklama, porušení obchodního tajemství, dotěrné obtěžování a ohrožení zdraví a životního prostředí. Tento výčet je pouze demonstrativní a ponechává prostor pro jiný, zákonem př́mo nedefinovaný typ nekalé soutěže, který naplní znaky základní definice nekalé soutěže.

Důležité je zmínit, že klamavý může být i údaj, který je sám o sobě správný, ale vzhledem k okolnostem a souvislostem může někoho uvést v omyl.

Příkladů z oblasti divadla je mnoho, ale podle mnou dohledaných informací žádný $\mathrm{z}$ těchto př́ípadu nedospěl k soudu.

V divadelním prostředí se vyskytují především následující typy nekalé soutěže: Klamavá reklama, klamavé označování zboží a služeb, vyvolání nebezpečí záměny, parazitování na pověsti závodu, výrobku či služeb jiného soutěžitele, zlehčování, srovnávací reklama, pokud není dovolena jako přípustná, porušení obchodního tajemství a dotěrné obtěžování.

U nekalé soutěže je možné některé chování kvalifikovat jako různé typy nekalé soutěže, vždy záleží na úhlu pohledu a převládajících znacích jednotlivých porušení.

Jedním z př́íkladů je název dvou institucí, Divadla Na zábradlí a Divadla Bez zábradlí. Máme zde dva subjekty, Divadlo Na zábradlí, divadlo s dlouholetou historií s první premiérou v roce 1958, a Divadlo Bez zábradlí založené v roce 1990 . V tomto př́ípadě se domnívám, že mohly být naplněny znaky klamavého označení zboží nebo služby, vyvolání nebezpečí záměny nebo parazitování na pověsti závodu, výrobku či služeb jiného soutěžitele. V prvním případě produkt „Divadlo Bez zábradlí“ je označen tak, že se laická veřejnost může velmi jednoduše domnívat, že se jedná o „Divadlo Na zábradlí“ a jeho repertoár. Stejně tak i vyvolání nebezpečí záměny a parazitování na pověsti ukazuje na to, že název „Divadlo Bez zábradlí“ byl vybrán úmyslně. Diváci, především příležitostní návštěvníci divadel, nikoli odborná veřejnost, věděli o existenci divadla, které má v názvu „zábradlí“ a nenapadlo je, že existují dvě divadla, která mají v názvu „zábradlí“. $\mathrm{V}$ počátcích existence druhého zmíněno divadla se tak často stávalo, že diváci chodili se zakoupenými vstupenkami do špatného divadla. Na tomto př́kladu je vidět, že by opravdu záleželo na konkrétních okolnostech, která zákonná definice nekalé soutěže by v tomto př́ípadě byla naplněna. Tento případ nebyl soudně projednáván, nelze tudíž 
jednoznačně říct, zda by soud rozhodl o porušení ustanovení nekalé soutěže. Dle dostupných informací se domnívám, že by soud, pokud by byla podána žaloba, v tomto případě rozhodl o porušení ustanovení o nekalé soutěži.

O využití ustanovení nekalé soutěže se dá uvažovat na ochranu originálních dramaturgických nápadů, dramatizací ojedinělých titulů, zvláštních postupů zkoušení inscenace, metod získávání diváků či vedení databáze, apod., tedy toho co je vyloučeno z ochrany AZ dle $§ 2$ (6) AZ, jelikož není považováno za dílo.

Př́kladem by mohl být dramaturgický nápad Pavla Kohouta, který v rámci úpravy hry Cyrano z Bergeracu seškrtal a změnil původních 17 postav a vznikl Cyrano!!. Jakub Špalek poté udělal téměř totéž̌ ${ }^{24}$ : použil jeho nápad s úpravou díla, ale vycházel z jiného překladu, nešlo tedy brát jako porušení autorského práva. $\mathrm{V}$ tomto př́padě by se dalo uvažovat o ochraně dle ustanovení o nekalé soutěži, jelikož Pavel Kohout přišel o tantiémy, na které by měl nárok, pokud by se použila jeho úprava díla.

Srovnávací reklama u divadla není př́lišs běžná, ale taktéž se může vyskytnout. Divadlo by v ní přímo nebo nepř́ímo označovalo jiné divadlo (nebo jeho produkt) a srovnávalo se svým produktem v rozporu se zákonnými ustanoveními.

Zlehčování, další typ nekalé soutěže, úzce souvisí se srovnávací reklamou. Zde by soutěžitel šíril nepravdivé údaje, př́ípadně i pravdivé, pokud by mohly způsobit újmu, o jiném soutěžiteli. Oba tyto typy nekalé soutěže poškozují především dobrou pověst divadla jako takového a jeho ,produktu“.

K porušení obchodního tajemství může dojít velmi jednoduše: někdo ze zaměstnanců divadla, případně někdo v obdobném vztahu $\mathrm{k}$ divadlu, neoprávněně sdělí či zpř́ístupní tajemství využitelné v soutěži. Není podstatné, jestli užitek půjde jemu osobně či ve prospěch třetí osoby. Jak jsem již psala v kapitole o obchodním tajemství, jednalo by se především o zpřístupnění databáze diváků nebo o způsob sestavování repertoáru.

Za dotěrné obtěžování by mohlo být v kontextu divadla považováno zasílání nevyžádaných newsletterů, dotazníkových šetření či obchodních nabídek. V případě, že divadla získala kontakty v souvislosti s prodejem zboží či služby, což tak ve většině případů je, a druhá strana nezakázala využití elektronické adresy, o dotěrné obtěžování by se nejednalo.

Zdůrazňuji, že u všech typů nekalé soutěže je nutné, aby byla splněna podmínka způsobilosti přivodit újmu jiným soutěžitelům nebo zákazníkům, jinak by nenaplnilo zákonné znaky nekalé soutěěe.

24 Pavel Kohout k tomu v roce 2004 v rozhovoru uvedl: „Navíc Cyrano má, čemu říkám zlaté jádro. To jsem asi před pětadvaceti lety vyoperoval ze všeho toho balastu a bombastu jako příběh pro sedm herců, který se pak hrál v několika evropských divadlech, zatímco tady si jej bez udání adaptátora vypůjčil pro svou krásnou inscenaci Jakub Špalek, takže jsem mu musel zjevit, že porušuje autorská práva.“ Dostupné online na http://host.divadlo.cz/noviny/archiv2004/cislo13/priloha.html. Podobné př́íklady z praxe lze najít např́íklad v tomto článku z Divadelních novin „Kdo ho má?!“. Divadelni noviny [online]. Praha, 2012 [citováno dne 11. 12. 2016]. Dostupné online na http://www.divadelni-noviny.cz/kdo-ho-ma. 


\section{Závěr}

Právo duševního vlastnictví je v dnešní době stále častěji skloňovaným termínem. Již i divadelní „nezisková“ ${ }^{25}$ sféra si začíná pečlivě hlídat svá práva v této oblasti. V současné době dochází, i díky moderním technologiím, relativně často ke vzájemnému přesahu a prolínání jednotlivých práv. Při vyhledávání př́kladů z divadel jsem pochopila, proč se právo duševního vlastnictví, mimo autorský zákon, v divadlech příliš neřeší. Energie a př́ípadné finance na řešení sporů se divadlům na rozdíl od komerční sféry nechtějí, a především ve většině případů nevyplatí vynakládat.

\section{Bibliografie}

\section{Právní předpisy a mezinárodní smlouvy}

Dohoda o obchodních aspektech práv k duševnímu vlastnictví (známá pod zkratkou TRIPS ${ }^{26}$ ) ze dne 15. dubna 1994 [Agreement on the Commercial Aspects of the Copyright Law (TRIPS), 15 Apr., 1994].

Směrnice Evropského parlamentu a Rady 2004/48/ES ze dne 29. dubna 2004 o dodržování práv duševního vlastnictví, v kombinaci s prohlášením Komise 2005/295/ES [Regulation of the European Parliment and the Council, no. 2004/48/ES, 29 Apr., 2004, on the observance of Copyright Legislation, combined with the Committee Declaration, no. 2005/295/ES].

Smlouva Světové organizace duševního vlastnictví (WIPO) o právu autorském z roku 1996 [WIPO Agreement on Copyright, 1996].

Úmluva o zřízení Světové organizace duševního vlastnictví ze 14. července 1967 [Foundation of WIPO Treaty, 14 Jul., 1967].

Zákon č. 89/2012 Sb., občanský zákoník [Act no. 89/2012 of the Statute Book, Civil Code].

Zákon č. 527/1990 Sb., o vynálezech a zlepšovacích návrzích [Act no. 527/1990 of the Statute Book, on inventions and improvement proposals].

Zákon č. 478/1992 Sb., o užitných vzorech [Act no. 478/1992 of the Statute Book, on utility models].

Zákon č. 441/2003 Sb., o ochranných známkách [Act no. 441/2003 of the Statute Book, on trademarks].

\section{Publikace}

HÁJKOVÁ, Martina. 2016. Právo duševniho vlastnictví v kontextu divadelniho provozu [Copyright Legislation in Theatre Management]. Praha, 2016. Diplomová práce [Diploma Thesis]. Akademie

25 Nezisková je zde použito zejména pro odlišení od subjektů, které jsou primárně založeny za účelem zisku.

26 Z anglického názvu Agreement on Trade-Related Aspects of Intellectual Property Rights. 
múzických umění v Praze [Academy of Performing Arts in Prague]. Divadelní fakulta [Theatre Faculty]. Vedoucí práce prof. JUDr. Jiří Srstka [Tutor: Professor Jiří Srstka].

DVOǨÁK, Jan. 2005. AMU = DAMU FAMU HAMU: kapitoly $k$ tématu realizace divadla [Academy of Performing Arts = Theatre Faculty, Film Faculty, Music and Dance Faculty. To the Issue of Theatre Production]. 3. vyd. Praha: Akademie múzických umění. Divadelní fakulta, Katedra produkce, 2005.

GREGORINI, Bedřich, Jindřich GREGORINI a Jiří SRSTKA. 2007. Základy divadelni činnosti: $[A M U=D A M U F A M U$ HAMU] [Introduction to Theatre Management (Academy of Performing Arts = Theatre Faculty, Film Faculty, Music and Dance Faculty)]. 1. vyd. Praha: Akademie múzických umění, Divadelní fakulta, Katedra produkce, 2007.

JOHNS, Adrian. 2013. Pirátstvi: boje o duševni vlastnictvi od Gutenberga po Gatese [Piracy: Fights Over the Copyright From Gutenberg To Gates]. 1. vyd. Brno: Host, 2013.

NEKOLNÝ, Bohumil. 2013. Divadlo a kreativni sektor [Theatre and Creative Sector]. 1. vyd. Praha: Akademie múzických umění v Praze, 2013.

Nový občanský zákonik a duševni vlastnictvi [New Civil Code and the Intellectual Property]. 1. vyd. Ladislav Jakl (ed.). Praha: Metropolitan University Prague Press, 2012.

SRSTKA, Jiří. 2006. Autorské právo v divadle: AMU=DAMU FAMU HAMU [Copyright in Theatre: Academy of Performing Arts = Theatre Faculty, Film Faculty, Music and Dance Faculty]. 1. vyd. Praha: Akademie múzických umění v Praze. Divadelní fakulta, Katedra produkce, 2006.

VOJČÍK, Peter. 2012. Právo duševného vlastníctva [The Intellectual Property Legislation]. Plzeň: Vydavatelství a nakladatelství Aleš Čeněk, 2012.

TELEC, Ivo. 2007. Přehled práva duševniho vlastnictvi [Overview of the Intellectual Property Legislation]. 2. vyd. Brno: Doplněk, 2007.

\section{Webové stránky}

Webové stránky Úřadu průmyslového vlastnictví [Website of the Industrial Property Office], dostupné online na http://www.upv.cz/cs.html.

Webové stránky Úřadu Evropské unie pro duševní vlastnictví [Website of the European Union Intellectual Property Office], dostupné online na https://euipo.europa.eu.

Webové stránky Světové organizace duševního vlastnictví [Website of the World Intellectual Property Organization], dostupné online na http://www.wipo.int/.

Informační portál ministerstva spravedlnosti k rekodifikaci soukromého práva [Information Website of the Ministry of Justice for the recodification of the Private Law], dostupné online na http:/ / obcanskyzakonik.justice.cz/.

Webové stránky eprávo [ePrávo (Electronic Law) Website], dostupné online na http://www. epravo.cz/. 


\section{Markéta Hájková}

Institut plánování a rozvoje hlavního města Prahy

hajkovamm@gmail.com

Markéta Hájková je absolventkou Právnické fakulty Univerzity Karlovy v Praze a Produkce DAMU, která se dlouhodobě věnuje aplikaci práva duševního vlastnictví v oblasti divadla. $\checkmark$ současné době pracuje pro Institut plánování a rozvoje hlavního města Prahy a spolupracuje s Asociací profesionálních divadel ČR.

Having graduated at the Faculty of Law, Charles University, and in Theatre Management at the Theatre Faculty, Academy of Performing Arts (CZ), Markéta Hájková deals in her professional career with the application of the Intellectual Property Right in theatre. She has a position in the Prague Institute of Planning and Development, and collaborates with the Association of Professional Theatres in the Czech Republic. 